\title{
Tissue-specific regulation of inflammation by macrophage migration inhibitory factor and glucocorticoids in fructose-fed Wistar rats
}

\author{
Nataša Veličković*, Ana Djordjevic, Ana Vasiljević, Biljana Bursać, Danijela Vojnović Milutinović and \\ Gordana Matić \\ Department of Biochemistry, Institute for Biological Research "Siniša Stankovič", University of Belgrade, 142 Despot Stefan \\ Boulevard, 11000 Belgrade, Serbia
}

(Submitted 10 August 2012 - Final revision received 19 October 2012 - Accepted 19 October 2012 - First published online 3 January 2013)

\begin{abstract}
High fructose consumption is commonly associated with insulin resistance, disturbed glucose homeostasis and low-grade inflammation. Increased glucocorticoid production within adipose tissue has been implicated in the pathogenesis of fructose-induced metabolic syndrome. Immunosuppressive actions of glucocorticoids can be counter-regulated by macrophage migration inhibitory factor (MIF), which is recognised as a key molecule in metabolic inflammation. In the present study, we hypothesised that coordinated action of glucocorticoids and MIF can mediate the effects of a high-fructose diet on adipose tissue and liver inflammation. We examined the effects of long-term consumption of a $10 \%$ fructose solution on corticosterone (CORT) and MIF levels in rat blood plasma, liver and adipose tissue, as well as MIF and TNF- $\alpha$ mRNA expression and NF- $\mathrm{BB}$ activation in the same tissues. The high-fructose diet led to an increase in both CORT and MIF in the adipose tissue, and a highly significant positive correlation between their levels was observed. The attenuated NF- $\kappa \mathrm{B}$ activation and unaltered TNF- $\alpha$ mRNA expression noticed in the adipose tissue could be interpreted as an outcome of the opposing actions of CORT and MIF. In contrast to adipose tissue, inflammation in the liver was characterised by NF- $\kappa \mathrm{B}$ activation, an increased TNF- $\alpha$ mRNA level and unchanged levels of MIF protein, MIF mRNA and CORT. Overall, these findings suggest that a high-fructose diet differently affects the levels of glucocorticoids and MIF in the adipose tissue and liver, implicating that fructose over-consumption has tissue-specific effects on regulation of metabolic inflammation.
\end{abstract}

Key words: Glucocorticoids: Macrophage migration inhibitory factor: Fructose diet: Inflammation

Fructose intake from added sugars has increased dramatically over the last decades and has been considered as a potential contributor to insulin resistance, dyslipidaemia, hypertension and inflammation, through dysregulation of many signalling and metabolic pathways ${ }^{(1,2)}$. A hallmark of the metabolic syndrome is adipose tissue dysfunction, resulting in impaired TAG storage in the adipose tissue and increased levels of circulating NEFA ${ }^{(3)}$. Such a condition has been associated with chronic inflammation, characterised by accumulation of adipose tissue macrophages and higher secretion of proinflammatory cytokines ${ }^{(4)}$. On the other hand, high flux of NEFA from the blood to the liver increases lipid availability, promotes hepatic insulin resistance and perturbs inflammatory signalling ${ }^{(5)}$

Metabolic inflammation is an important mediating link between obesity and several metabolic abnormalities, including insulin resistance and liver fat accumulation ${ }^{(6)}$. The NF-кB signalling pathway has been recognised as a 'master-switch' control system in generating metabolic inflammation $^{(7)}$. NF- $\mathrm{kB}$ represents a heterodimeric complex consisting of a subunit of $50 \mathrm{kDa}(\mathrm{p} 50)$ and a subunit of $65 \mathrm{kDa}$ $(\mathrm{p} 65 \text { or RelA })^{(8)}$. In unstimulated cells, NF- $\mathrm{kB}$ is sequestered in the cytoplasm in an inactive complex with one of the isoforms of the inhibitory protein $\kappa \mathrm{B}$ (IкB). Activation of NF- $\mathrm{B}$ by inflammatory cytokines, such as IL- $1 \beta$ and TNF- $\alpha$, leads to ІкB phosphorylation and its degradation by proteasomes. The released NF- $\mathrm{kB}$ then translocates to the nucleus and binds to specific $\kappa \mathrm{B}$ DNA sequences, thereby initiating the transcription of proinflammatory genes ${ }^{(8)}$. Among numerous cytokines, TNF- $\alpha$ was identified as the most important proinflammatory mediator in metabolic inflammation, as this cytokine is overexpressed in the adipose tissue of rodent models of obesity ${ }^{(9)}$. Circulating TNF- $\alpha$ concentration rises with increasing obesity and correlates with insulin resistance ${ }^{(10)}$, while obese mice lacking functional TNF- $\alpha$ or TNF receptors have improved insulin sensitivity ${ }^{(11)}$. Therefore, the overproduction of TNF- $\alpha$ is an

Abbreviations: $11 \beta$-HSD1, $11 \beta$-hydroxysteroid dehydrogenase type 1 ; BSA, bovine serum albumin; cDNA, complementary DNA; CORT, corticosterone; IкB, inhibitory protein $\kappa \mathrm{B}$; MIF, macrophage migration inhibitory factor.

*Corresponding author: N. Veličković, fax +381 1127614 33, email nvelickovic@ibiss.bg.ac.rs 
important feature of obesity and metabolic inflammation, contributing significantly to insulin resistance.

The other cytokine recognised as a key molecule in the genesis of metabolic inflammation is macrophage migration inhibitory factor (MIF) ${ }^{(12)}$. MIF is an innate cytokine involved in many inflammatory and autoimmune disorders. It is secreted by activated immune cells, anterior pituitary cells and $\beta$-cells of the pancreatic islets ${ }^{(13)}$. MIF amplifies the proinflammatory cascade and controls the 'set point' and magnitude of inflammation ${ }^{(14)}$. It was proposed that MIF and TNF- $\alpha$ could function locally in a reciprocal stimulatory 'loop' to activate a proinflammatory response ${ }^{(15)}$. MIF also controls metabolic processes maintaining glucose homeostasis and functions as a positive, autocrine regulator of insulin release from the pancreas ${ }^{(16)}$. Intriguingly, MIF was found to counter-regulate the anti-inflammatory effects of glucocorticoids on immune cell activation and cytokine production ${ }^{(17)}$.

Glucocorticoids are potent regulators of energy metabolism and their role in the progression of the metabolic syndrome has been extensively investigated in recent years. In addition to production by the adrenal glands, glucocorticoids are also produced within the tissues by the enzyme $11 \beta$-hydroxysteroid dehydrogenase type 1 (11 $\beta$-HSD1). Accumulating evidence has demonstrated that in the metabolic syndrome, local levels of glucocorticoids (corticosterone (CORT) in rats) in the adipose tissue are increased without a concomitant change in their systemic levels, most probably through enhanced activity of $11 \beta-H S D 1^{(18,19)}$. Apart from their metabolic role, the major actions of glucocorticoids include the suppression of multiple proinflammatory genes, such as those encoding cytokines, chemokines, adhesion molecules and cytokine receptors. The anti-inflammatory actions of glucocorticoids are mediated by interactions of the glucocorticoid receptor with proinflammatory transcription factors NF- $\mathrm{BB}$ and activator protein- $1^{(20)}$, resulting in the negative regulation of numerous inflammatory genes.

An area of ambiguity in the aetiology of the metabolic syndrome is the functional relationship between glucocorticoids and inflammatory mediators, as both are up-regulated in dietinduced metabolic disturbances, in spite of anti-inflammatory actions of glucocorticoids. In the present study, we tested the hypothesis that a coordinated action of glucocorticoids and MIF can modulate inflammation in rat adipose tissue and liver after a long-term high-fructose diet. To test this hypothesis, we examined both CORT and MIF levels in the blood plasma, adipose tissue and liver of fructose-fed rats. The effects of the highfructose diet on inflammation were further analysed at the level of NF- $\mathrm{B}$ compartmental redistribution and expression of TNF- $\alpha$ mRNA in the adipose tissue and liver.

\section{Experimental methods}

\section{Animals and treatment}

Experiments were conducted on male Wistar rats aged $21 \mathrm{~d}$, bred in our laboratory. The animals were maintained under a $12 \mathrm{~h}$ light $-12 \mathrm{~h}$ dark cycle (lights on at 07.00 hours) at $22^{\circ} \mathrm{C}$ and constant humidity. At the beginning of the experiment, rats were divided into two groups (nine rats per group) and housed three per cage. The control group had a standard diet (commercial food; Veterinary Institute Subotica) and drinking water available ad libitum, while the treated group (fructosefed rats) had a high-fructose diet (commercial food and 10\% fructose solution (API-PEK) in drinking water available ad libitum) during the 9 weeks. The detailed composition of the diets is presented in Table 1. Body mass of the rats in the two

Table 1. Diet composition*

\begin{tabular}{|c|c|c|}
\hline Chemical composition & Normal diet & High-fructose diet \\
\hline Metabolisable energy, not less than & $11000 \mathrm{~kJ} / \mathrm{kg}$ & $11000 \mathrm{~kJ} / \mathrm{kg}$ diet $+1720 \mathrm{~kJ} / \mathrm{l}$ solution \\
\hline Protein, not less than (\%) & 20 & 20 \\
\hline Fructose as solution & 0 & $100 \mathrm{~g} / \mathrm{l}$ \\
\hline Moisture, not more than (\%) & 13 & 13 \\
\hline Ash, not more than (\%) & 10 & 10 \\
\hline Cellulose, not more than (\%) & 8 & 8 \\
\hline $\mathrm{Ca}$, not less than $(\%)$ & 1 & 1 \\
\hline Lys, not less than (\%) & 0.90 & 0.90 \\
\hline Met + cystine, not less than (\%) & 0.75 & 0.75 \\
\hline $\mathrm{P}$, not less than $(\%)$ & 0.50 & 0.50 \\
\hline $\mathrm{Na}(\%)$ & $0.15-0.25$ & $0.15-0.25$ \\
\hline Vitamin A, not less than (mg/kg) & 3440 & 3440 \\
\hline Vitamin $D_{3}$, not less than $(\mathrm{mg} / \mathrm{kg})$ & 0.04 & 0.04 \\
\hline Vitamin $E$, not less than $(\mathrm{mg} / \mathrm{kg})$ & 25 & 25 \\
\hline Vitamin $B_{12}$, not less than $(\mathrm{mg} / \mathrm{kg})$ & 0.02 & 0.02 \\
\hline $\mathrm{Zn}$, not less than $(\mathrm{mg} / \mathrm{kg})$ & 100 & 100 \\
\hline $\mathrm{Fe}$, not less than $(\mathrm{mg} / \mathrm{kg})$ & 100 & 100 \\
\hline Mn, not less than $(\mathrm{mg} / \mathrm{kg})$ & 30 & 30 \\
\hline $\mathrm{Cu}$, not less than $(\mathrm{mg} / \mathrm{kg})$ & 20 & 20 \\
\hline I, not less than $(\mathrm{mg} / \mathrm{kg})$ & 0.5 & 0.5 \\
\hline Se, not less than $(\mathrm{mg} / \mathrm{kg})$ & 0.1 & 0.1 \\
\hline Antioxidant, not less than $(\mathrm{mg} / \mathrm{kg})$ & 100 & 100 \\
\hline
\end{tabular}

* Control animals had free access to tap water and standard laboratory chow. Animals on the fructose-enriched diet were fed with the same food, but water was replaced with $10 \%(\mathrm{w} / \mathrm{v})$ fructose solution in tap water. Animals were exposed to these diets for 9 weeks. 
experimental groups was not significantly different at the beginning of the diet. Daily food and fluid intake was measured during the treatment. Energy intake for fructose-fed rats was calculated as the sum of energy ingested as food and fructose solution. All the protocols complied with the European Communities Council Directive (86/609/EEC) and were approved by the Ethical Committee for the Use of Laboratory Animals, according to the guidelines of the European Union registered Serbian Laboratory Animal Science Association.

\section{Blood plasma preparation and tissue collection}

After overnight fasting, animals were killed by decapitation with a guillotine (Harvard-Apparatus) always at the same time (09.00-10.00 hours). Trunk blood was rapidly collected into EDTA-containing tubes and agitated slowly. Plasma was isolated by centrifugation at $1600 \mathrm{~g}$ for $10 \mathrm{~min}$ at room temperature and then stored at $-20^{\circ} \mathrm{C}$ for subsequent processing. After blood collection, livers were perfused with cold $0 \cdot 9 \% \mathrm{NaCl}$. The livers and the omental visceral adipose tissues were carefully excised and kept in liquid $\mathrm{N}_{2}$ until RNA and protein isolation.

\section{Corticosterone assay}

Plasma was used for CORT measurement in the circulation, while adipose tissue and liver cytoplasmic fractions were used for assessment of tissue CORT. Plasma and tissue CORT concentrations were determined by a Corticosterone High Sensitivity EIA kit (IDS, American Laboratory Products Company), according to the manufacturer's instructions. The standards and samples were measured in duplicate. The plates were read at 450 and $650 \mathrm{~nm}$ on the Multiskan Spectrum (Thermo Electron Corporation). The hormone concentrations were determined using the 4PL curve-fitting method (GraphPad Prism 5; GraphPad Software, Inc.) and are given as ng/ $\mathrm{ml}$ for plasma and as $\mathrm{ng} / \mathrm{mg}$ protein for tissues.

\section{Preparation of cytoplasmic and nuclear fractions}

The livers were weighed and homogenised with a Janke-Kunkel ultraturax in four volumes (w/v) of ice-cold homogenisation buffer (20 mm-Tris- $\mathrm{HCl}, \mathrm{pH} 7 \cdot 2,10 \%$ glycerol, $50 \mathrm{~mm}-\mathrm{NaCl}, 1 \mathrm{~mm}-\mathrm{EDTA}-\mathrm{Na}_{2}, 1 \mathrm{~mm}$-ethylene glycol tetraacetic acid- $\mathrm{Na}_{2}, 2 \mathrm{~mm}$-dithiothreitol, protease and phosphatase inhibitors). The visceral adipose tissue was pooled (each pool consisting of adipose tissue from two to three animals) and homogenised in one volume (w/v) of homogenisation buffer by the same protocol. The cell lysates from both tissues were filtered through gauze and after centrifugation (2000 g, $15 \mathrm{~min}, 4^{\circ} \mathrm{C}$, Eppendorf centrifuge), the resulting supernatants and pellets were further processed to generate cytoplasmic and nuclear fractions, respectively. The supernatants were centrifuged $\left(10000 \mathrm{~g}, 30 \mathrm{~min}, 4^{\circ} \mathrm{C}\right.$, Sorvall SSA1 rotor) and recentrifuged in a Beckman ultracentrifuge $\left(200000 \mathrm{~g}, 90 \mathrm{~min}, 4^{\circ} \mathrm{C}\right)$; final supernatants were used as the cytoplasmic fraction. For nuclear fraction preparation, pellets from the first centrifugation were washed twice in
HEPES buffer (25 mm-HEPES, pH 7·6, $10 \%$ glycerol, 50 mm-NaCl, 1 mM-EDTA-Na 2,1 mM-ethylene glycol tetraacetic acid- $\mathrm{Na}_{2}$, $2 \mathrm{~mm}$-dithiothreitol, protease and phosphatase inhibitors), pelleted $\left(4000 \mathrm{~g}, 10 \mathrm{~min}, 4^{\circ} \mathrm{C}\right.$, Eppendorf centrifuge) and resuspended in one volume of NUN buffer ( 25 mM-HEPES, $\mathrm{pH}$ 7·6, 1 м-urea, $300 \mathrm{~mm}-\mathrm{NaCl}, 1 \%$ Nonidet P-40, protease and phosphatase inhibitors). After incubation on ice for $60 \mathrm{~min}$ with continuous agitation and frequent vortexing, nuclear lysates were centrifuged $\left(20000 \mathrm{~g}, 30 \mathrm{~min}, 4^{\circ} \mathrm{C}\right.$, Eppendorf centrifuge) and the supernatants were used as final nuclear fractions. All steps were conducted at $0-4^{\circ} \mathrm{C}$ and all samples were aliquoted and stored at $-70^{\circ} \mathrm{C}$. Protein content of the fractions was determined by the method of Spector ${ }^{(21)}$ using bovine serum albumin (BSA) as a standard.

\section{RNA extraction and RT}

Total RNA was isolated from the liver and visceral adipose tissues using TRIreagent ${ }^{\circledR}$ (AmBion, Inc.). RNA was quantified by reading the optical density at 260 and $280 \mathrm{~nm}$. For the synthesis of complementary DNA (cDNA), a High-Capacity cDNA Reverse Transcription Kit (Applied Biosystems Materials, Inc.) was used according to the manufacturer's instructions. RT was performed from $2 \mu \mathrm{g}$ of total RNA using MultiScribe ${ }^{\mathrm{TM}}$ Reverse transcriptase $(50 \mathrm{U} / \mu \mathrm{l})$ in the presence of $2 \mu \mathrm{l}$ random primers, $0.8 \mu \mathrm{l} 100 \mathrm{~mm}$-deoxyribonucleotide triphosphates (dNTIP) mix, $1 \mu \mathrm{l}$ of RNase inhibitor and 10× RT buffer in a final volume of $20 \mu \mathrm{l}$. The cDNA were stored at $-70^{\circ} \mathrm{C}$ until analysis.

\section{TaqMan ${ }^{\circledR}$ Real-Time PCR}

Quantification of MIF gene expression in the liver and adipose tissue was performed by TaqMan ${ }^{\circledR}$ Real-Time PCR. MIF (Rn00821234_g1*) and all primers and probes were obtained from Applied Biosystems Assay-on-Demand Gene Expression Products. $\beta$-Actin (Rn00667869_m1*) and TATA-box protein (Rn01455646_m1*) were used as internal controls for quantitative normalisation of cDNA in the liver and adipose tissue, respectively ${ }^{(22)}$. Real-time PCR was performed using the ABI Prism 7000 Sequence Detection System (Applied Biosystems) in a total volume of $25 \mu \mathrm{l}$ containing 1× TaqMan Universal Master Mix with AmpErase UNG, $1 \times$ Assay Mix (Applied Biosystems) and cDNA template (10 ng). Thermocycler conditions comprised an initial step at $50^{\circ} \mathrm{C}$ for $5 \mathrm{~min}$, followed by another at $95^{\circ} \mathrm{C}$ for $10 \mathrm{~min}$ and a subsequent two-step PCR programme at $95^{\circ} \mathrm{C}$ for $15 \mathrm{~s}$ and at $60^{\circ} \mathrm{C}$ for $60 \mathrm{~s}$ and forty cycles. No template control was used in each run. All reactions were run in triplicate. Additional validation of PCR efficiencies of all genes was performed. Serial dilutions of one randomly chosen cDNA were made and amplified, and standard curves constructed. Amplification efficiencies (E\%) were calculated using the formula $E=\left(10^{-1 / \text { slope }}-1\right) \times 100$. Relative quantification of gene expression was calculated using the comparative $2^{-\Delta \Delta C_{t}}$ method described by Livak \& Schmittgen ${ }^{(23)}$. The results were analysed by Sequence Detection Software version 1.2.3 for 7000 System SDS Software RQ Study Application (Applied Biosystems), with a confidence level of $95 \%(P \leq 0 \cdot 05)$. 


\section{SYBR ${ }^{\circledR}$ Green Real-Time PCR}

Determination of TNF- $\alpha$ gene expression in the analysed tissues was performed by SYBR ${ }^{\circledR}$ Green Real-Time PCR using Power SYBR ${ }^{\circledR}$ Green PCR Master Mix (Applied Biosystems) in a total volume of $20 \mu \mathrm{l}$ in an ABI PRISM 7000 Sequence Detection System (Applied Biosystems). The cDNA were amplified using the following conditions: $50^{\circ} \mathrm{C}$ for $2 \mathrm{~min}$ for $2^{\prime}$-deoxyuridine $5^{\prime}$-triphosphate (dUTP) activation, $95^{\circ} \mathrm{C}$ for $10 \mathrm{~min}$ for initial denaturation, followed by forty cycles at $95^{\circ} \mathrm{C}$ for $15 \mathrm{~s}$ and $60^{\circ} \mathrm{C}$ for $60 \mathrm{~s}$. Specific primers (Metabion) were used to selectively amplify TNF- $\alpha$ : forward $5^{\prime}$-TCG AGT GAC AAG CCC GTA GC- $3^{\prime}$, reverse $5^{\prime}$-CTC AGC CAC TCC AGC TGC TC- $3^{\prime}$ and $\beta$-actin: forward $5^{\prime}$-CCC TGG CTC CTA GCA CCA T- $3^{\prime}$, reverse $5^{\prime}$-GAG CCA CCA ATC CAC ACA GA- $3^{\prime}$. $\beta$-Actin was used as an endogenous control to normalise the amount of cDNA in each sample ${ }^{(24,25)}$. The melting curve analyses were performed at the end of every experiment to confirm formation of a single PCR product. The lack of primer-dimer complexes and the presence of an appropriate single peak in the resultant melting curve were indicators of correct amplification products. Each sample was run in triplicate and no template control was included in each run as a negative control. The results were analysed with the 7000 System SDS Software RQ Study Application (Applied Biosystems) and presented as $2^{-\Delta C_{\mathrm{t}}}$, where $\Delta C_{\mathrm{t}}$ represents the difference between the $C_{\mathrm{t}}$ value of the target gene and the endogenous control.

\section{Cytokine immunoassay}

Levels of MIF in the plasma of fructose-fed and control rats were determined by a specific ELISA assay using pairs of specific antibodies (goat polyclonal anti-MIF antibody, M3895-07A, US Biological and goat polyclonal anti-MIF antibody, M3895-07B (biotin), US Biological). In brief, ninetysix-well plates were incubated overnight at $4{ }^{\circ} \mathrm{C}$ with $50 \mu \mathrm{l}$ of polyclonal anti-MIF antibody (M3895-07A) in carbonate buffer ( $15 \mathrm{~mm}-\mathrm{Na}_{2} \mathrm{CO}_{3}, 15 \mathrm{~mm}-\mathrm{NaHCO}_{3}, 3 \mathrm{~mm}-\mathrm{NaN}_{3}, \mathrm{pH}$ 9.6), washed several times with PBS containing 0.1\% Tween 20, blocked for $2 \mathrm{~h}$ at room temperature with $200 \mu \mathrm{l}$ of blocking buffer (PBS, pH 7.3, containing 2\% BSA) and washed. MIF standards $(50 \mu \mathrm{l} ; 0-20 \mathrm{ng} / \mathrm{ml}$ in PBS containing $2 \% \mathrm{BSA})$ or samples (plasma obtained by whole blood centrifugation at $3000 \mathrm{~g}$ for $15 \mathrm{~min}$ ) in duplicates were added and incubation proceeded for $2 \mathrm{~h}$ at $37^{\circ} \mathrm{C}$. Secondary antibody $(50 \mu \mathrm{l}$; biotinylated anti-MIF antibody, M3895-07B) was added and incubated for $1 \mathrm{~h}$ at $37^{\circ} \mathrm{C}$. The wells were washed and the detection agent ( $50 \mu \mathrm{l}$; horseradish peroxidase-conjugated streptavidin; 1:1000 dilution in PBS containing 2\% BSA) was added and incubated for $30 \mathrm{~min}$ at $37^{\circ} \mathrm{C}$. Substrate solution $(50 \mu \mathrm{l}$; tetramethylbenzidine) was added and incubated at room temperature in the dark for $20 \mathrm{~min}$. The reaction was stopped using $25 \mu \mathrm{l}$ of $1 \mathrm{M}$ $\mathrm{H}_{3} \mathrm{PO}_{4}$. Absorbance was read at 450 and $650 \mathrm{~nm}$ on the Multiskan Spectrum (Termo Electron Corporation).

Tissue level of MIF was measured using cytoplasmic extracts from the adipose tissue and liver. MIF standards $(0-40 \mathrm{ng} / \mathrm{ml}$ in PBS containing $2 \%$ BSA) and cytoplasmic extracts $(50 \mu \mathrm{l}, 2 \mu \mathrm{g} / \mu \mathrm{l})$ were analysed for concentration of MIF by ELISA using the same pairs of antibodies and aforementioned protocol. Absorbance was read at $450 \mathrm{~nm}$ on the Multiskan Spectrum (Termo Electron Corporation), subtracted from values obtained at $650 \mathrm{~nm}$ and the results were expressed as ng MIF per mg protein.

\section{Western blot analysis}

After boiling in Laemmli's buffer, $40 \mu \mathrm{g}$ of liver and adipose tissue proteins were resolved on $10 \%$ SDS-polyacrylamide gels. The samples intended to be compared were always run on the same gel. Separated proteins were transferred to polyvinylidene fluoride (PVDF) membranes (Immobilon-FL, Millipore). The blots were blocked by PBS (1.5 mM- $\mathrm{KH}_{2} \mathrm{PO}_{4}$,

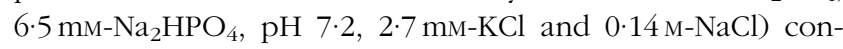
taining $2 \%$ non-fat dry milk for $1 \mathrm{~h}$ at room temperature. After extensive washing (PBS containing 0.1\% Tween 20), membranes were incubated overnight at $4^{\circ} \mathrm{C}$ with primary NF-кB (p65 subunit) antibody (C-20, Santa Cruz Biotechnology, 1:1000) or IкB- $\alpha$ (C-21, Santa Cruz Biotechnology, 1:500). Anti- $\beta$-actin (AC-15, Sigma-Aldrich, 1:10 000) was used as an equal load control. Membranes were subsequently washed and incubated for $90 \mathrm{~min}$ with alkaline phosphataseconjugated secondary antibodies (Amersham Pharmacia Biotech, 1:20000). The immunoreactive proteins were visualised by the enhanced chemifluorescence (ECF) method (Amersham Pharmacia Biotech) and quantitative analysis was performed by ImageQuant software (GE Healthcare).

\section{Statistical analysis}

All the data were expressed as means with their standard errors. A total of nine animals per group were used for measurements of plasma and tissue CORT and MIF ( $n$ 9). The quantitative RT-PCR data present the triplicate analysis of the RNA samples and are given as means with their standard errors ( $n$ 9). Data from Western blots are presented as means with their standard errors ( $n$ 9). The comparisons of means between the control and fructose-fed groups of animals were done using Student's unpaired $t$ test (two-tailed). The direction and strength of the relationships between variables were estimated using Spearman's rank correlation coefficients $\left(r_{\mathrm{S}}\right)$. When correlations achieved statistical significance, variables were entered into a linear regression model. Results were considered statistically significant at $P<0 \cdot 05$. Statistical analyses were done using SPSS software (version 13.0, SPSS Inc.) and GraphPad Prism 5 software (GraphPad Software, Inc.).

\section{Results}

\section{Effect of high-fructose diet on body composition and} energy intake in male Wistar rats

Rats on the fructose diet displayed significantly decreased food intake $(P<0.05)$, increased liquid intake $(P<0.05)$ and increased total energy intake $(P<0.05)$, as compared with control rats (Table 2). Despite increased energy intake, 
fructose-fed rats exhibited no significant differences in body weight, visceral adipose tissues and liver masses or organto-body weight ratio, compared with rats on the control diet (Table 2).

\section{Corticosterone levels in the plasma, adipose tissue and liver}

Fructose-fed rats showed normal circulating CORT levels in the plasma (control rats 177 ( $\operatorname{sem~39\cdot 1)~ng/ml;~fructose-fed~}$ rats $185.5(\mathrm{sEM} 44 \cdot 8) \mathrm{ng} / \mathrm{ml}$ ) (Table 3 ). To evaluate the effect of the high-fructose diet on intracellular glucocorticoids in the adipose tissue and liver, CORT levels were determined in the cytoplasmic extracts by hypersensitive ELISA. CORT level was significantly increased in the adipose tissue of fructose-fed rats $(P<0.05)$, while its level in the liver was not changed, as compared with animals on the control diet (Table 3).

\section{Macrophage migration inhibitory factor level in the plasma, adipose tissue and liver}

Measurement of MIF level was done in the plasma of fructosefed rats and compared with the controls. ELISA revealed a trend towards a higher plasma MIF level in the animals on the fructose diet, but the difference was not statistically significant (Table 3, $P=0 \cdot 08$ ). Further analyses demonstrated significant positive correlation between visceral adipose tissue mass and plasma MIF in both control and fructose-fed rats $\left(r_{\mathrm{S}} 0.73\right.$, $P=0 \cdot 0012)$. On the other hand, the high-fructose diet led to increased MIF protein in the adipose tissue (Table 3, $P<0.05)$, though this increment was not accompanied by elevated MIF mRNA (Fig. 1). In the liver, MIF protein and MIF mRNA (Table 3 and Fig. 1) were not changed in fructose-fed rats, as compared with control animals. In both experimental groups, a correlation between CORT and MIF in the adipose tissue was statistically significant $\left(r_{\mathrm{S}} 0 \cdot 68, P=0 \cdot 007\right.$, Fig. 2$)$.

\section{TNF- $\alpha$ gene expression in the adipose tissue and liver}

Fig. 3 shows TNF- $\alpha$ gene expression in the adipose tissue and liver of fructose-fed rats and control animals. TNF- $\alpha$ mRNA level in the adipose tissue was similar between the two

Table 2. Body composition and energy intake of male Wistar rats after 9 weeks on a high-fructose or control diet

(Mean values with their standard errors, $n$ 9)

\begin{tabular}{|c|c|c|c|c|}
\hline \multirow[b]{2}{*}{ Diet } & \multicolumn{2}{|c|}{ Control } & \multicolumn{2}{|c|}{ Fructose } \\
\hline & Mean & SEM & Mean & SEM \\
\hline Body mass (g) & 348.33 & $12 \cdot 90$ & 341.67 & $13 \cdot 19$ \\
\hline Mass of VAT $(\mathrm{g})$ & 3.57 & 0.51 & $4 \cdot 10$ & 0.61 \\
\hline Mass of liver (g) & 12.52 & 0.60 & $12 \cdot 12$ & 0.59 \\
\hline VAT-to-body ratio $(\times 1000)$ & $10 \cdot 09$ & 1.37 & 11.68 & 1.50 \\
\hline Liver-to-body ratio $(\times 100)$ & 3.58 & 0.07 & 3.54 & 0.11 \\
\hline Food intake ( $\mathrm{g} / \mathrm{d}$ per animal) & 20.57 & $2 \cdot 63$ & $14 \cdot 20^{*}$ & 2.01 \\
\hline Liquid intake (ml/d per animal) & 49.33 & 5.39 & $74 \cdot 10^{\star}$ & 11.36 \\
\hline Energy intake ( $\mathrm{kJ} / \mathrm{d}$ per animal) & $226 \cdot 23$ & 28.90 & $283.65^{*}$ & 24.51 \\
\hline
\end{tabular}

VAT, visceral adipose tissue.

* Mean value was significantly different from that of the control rats $(P<0.05$; unpaired Student's $t$ test).
Table 3. Concentration of corticosterone (CORT) and macrophage migration inhibitory factor (MIF) in the plasma, adipose tissue and liver of male Wistar rats after 9 weeks on a high-fructose or control diet

(Mean values with their standard errors, $n$ 9)

\begin{tabular}{lrrrrr}
\hline & \multicolumn{2}{c}{ Control } & & \multicolumn{2}{c}{ Fructose } \\
\cline { 2 - 3 } \cline { 6 - 7 } Diet & \multicolumn{1}{c}{ Mean } & SEM & & Mean & SEM \\
\hline Plasma CORT $(\mathrm{ng} / \mathrm{ml})$ & 177.45 & 39.15 & & 185.51 & 44.84 \\
Adipose CORT $(\mathrm{ng} / \mathrm{mg})$ & 2.47 & 0.27 & & $5.17^{\star}$ & 0.97 \\
Liver CORT $(\mathrm{ng} / \mathrm{mg})$ & 0.31 & 0.03 & & 0.34 & 0.04 \\
Plasma MIF $(\mathrm{ng} / \mathrm{ml})$ & 10.97 & 0.91 & & 13.59 & 1.73 \\
Adipose MIF $(\mathrm{ng} / \mathrm{mg})$ & 30.49 & 3.77 & & $54.16^{\star}$ & 8.54 \\
Liver MIF $(\mathrm{ng} / \mathrm{mg})$ & 139.29 & 3.03 & & 140.30 & 3.95 \\
\hline
\end{tabular}

${ }^{*}$ Mean value was significantly different from that of the control rats $(P<0.05$; unpaired Student's $t$ test)

groups of animals. On the contrary, hepatic TNF- $\alpha$ mRNA level was significantly increased in the fructose-fed group compared with animals on the control diet (Fig. 3, $P<0 \cdot 05$ ).

\section{$N F-\kappa B$ protein level in the adipose tissue and liver}

The effects of the high-fructose diet on nucleo-cytoplasmic localisation of NF- $\mathrm{B}$, as a criterion of its activity, were examined by semi-quantitative Western blotting in the adipose tissue and liver. In the adipose tissue, a decrease in the level of NF-кB p65 subunit in the cytoplasmic fraction (Fig. 4, $P<0.05)$ was followed by its statistically insignificant increase in the nuclear fraction $(P=0 \cdot 17)$. To test whether the observed NF- $\kappa \mathrm{B}$ activation was I $\mathrm{B}$ dependent, changes of the total IкB- $\alpha$ content were assessed in the cytoplasmic fraction of the adipose tissue. The results demonstrated an unaltered level of total IкB- $\alpha$ in fructose-fed rats in comparison with the control animals.

$\mathrm{NF}-\kappa \mathrm{B}$ protein level in the liver was significantly increased in fructose-fed rats, as compared with control animals, both in the cytoplasmic and nuclear compartments (Fig. 5, $P<0 \cdot 05)$. The NF-кB increase of $20 \%$ above the control level was observed in the cytoplasmic fraction and was even

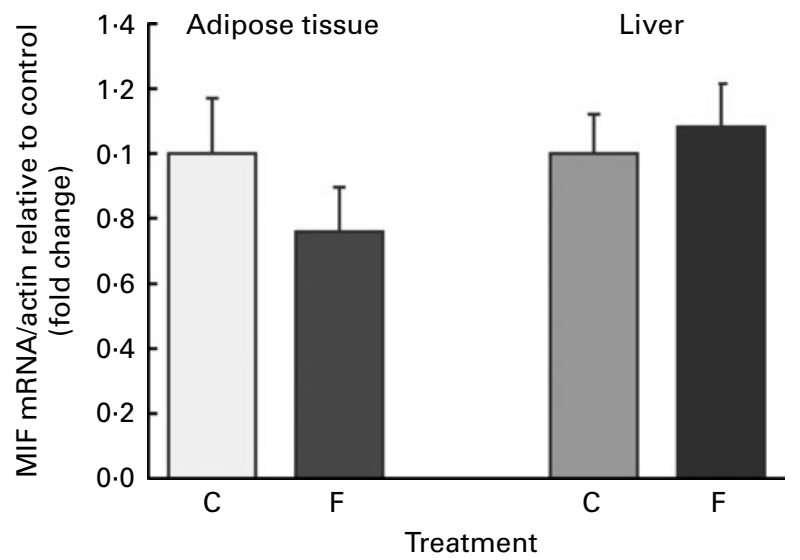

Fig. 1. Macrophage migration inhibitory factor (MIF) mRNA level in the adipose tissue and liver of control $(C)$ and fructose-fed $(F)$ rats. Expression and relative quantification of $\mathrm{mRNA}$ level were done relative to the amount of $\beta$-actin. Values are means, with their standard errors represented by vertical bars, and are presented as fold of control ( $n 9)$. Comparisons were made between $\mathrm{C}$ and $\mathrm{F}$ rats using the unpaired Student's $t$ test. 


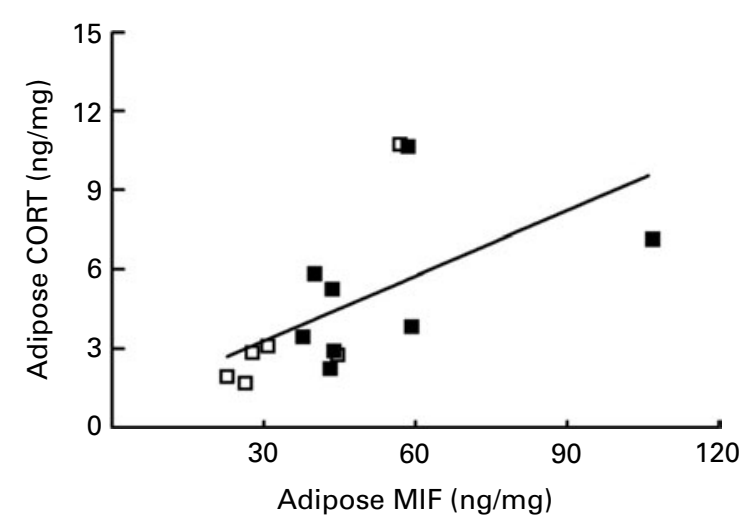

Fig. 2. Positive correlation between corticosterone (CORT) and macrophase migration inhibitory factor (MIF) in the adipose tissue of control rats $(\square)$ and fructose-fed rats $(\square)\left(n 9, r_{\mathrm{S}} 0.683, P=0.007\right)$.

more prominent in the nuclear fraction, where it amounted to $40 \%$ above the control level. The activation of NF-кB was additionally confirmed by a decreased level of total IкB- $\alpha$ in the liver cytoplasmic extracts of fructose-fed rats, in comparison with the control animals (Fig. 5; $P<0.05$ ).

\section{Discussion}

Recent human and animal studies have established both correlative and causative links between fructose consumption and chronic inflammation, in particular, in the adipose tissue and liver ${ }^{(2,26,27)}$. The aim of the present study was to assess the functional relationship between glucocorticoids and inflammatory mediators in the key metabolic tissues of Wistar rats after high fructose consumption. Our findings demonstrated that a fructose-rich diet led to a correlated increase in CORT and MIF levels and to attenuated activation of NF- $\mathrm{KB}$ signalling in the adipose tissue, implicating predominance of glucocorticoids over MIF effects on adipose tissue inflammation. On the other hand, both CORT and MIF were not changed in the liver of fructose-fed rats, whereas proinflammatory action was realised through NF-кB activation and TNF- $\alpha$ up-regulation.

Analysis of morphological parameters in the present study demonstrated that total body mass and absolute and relative visceral adipose tissue and liver masses were unaltered after 9 weeks of a fructose-rich diet. However, an increased energy intake was observed in the fructose-fed rats, most probably originating from over-consumption of fructose ${ }^{(28)}$. In theory, energy accumulation may be responsible for inflammation induction, preferably through metabolites of fatty acids and glucose ${ }^{(29)}$. The inflammation observed in the adipose tissue probably serves as a local feedback signal for energy expenditure, thus inhibiting adipocyte expansion and differentiation. The local response is translated into a systemic response through cytokines and NEFA released from the adipose tissue in the circulation, hence promoting energy expenditure systemically and decreasing energy accumulation in the adipose tissue ${ }^{(29)}$. In the present study, both body mass and relative visceral adipose tissue mass were unaffected by the applied diet regimen, which is most probably the result of increased adipose tissue lipolysis previously demonstrated by our group in the same animal model ${ }^{(30)}$.

Among the numerous cytokines, MIF represent a key molecule in the genesis of metabolic inflammation ${ }^{(12)}$. MIF is released from macrophages and $\mathrm{T}$ cells in response to physiological concentrations of glucocorticoids ${ }^{(17)}$, and its secretion follows a dose-response curve with respect to glucocorticoid concentration $^{(31)}$. Once released, MIF 'over-rides' or counterregulates the immunosuppressive effects of glucocorticoids on immune cell activation and cytokine production. In the present study, we found significantly increased MIF protein level and unchanged MIF mRNA level in the adipose tissue of fructose-fed rats, as compared with the controls. Besides, the fructose-rich diet did not affect the plasma levels of MIF and CORT, but CORT level in the visceral adipose tissue was significantly elevated, most probably due to increased activity of $11 \beta-H S D 1^{(25,30)}$. Moreover, correlation analysis revealed highly significant positive correlations between adipose CORT and MIF levels. These data are in accordance with a previously published observation that glucocorticoids can induce changes in MIF protein expression, without influencing its mRNA level ${ }^{(32)}$. However, the increase of MIF in the present study could also be a consequence of low-grade inflammation, which is usually observed in metabolic disturbances $^{(33)}$, as its main role within the inflammatory cascade is to conduct and enhance existing inflammatory signals ${ }^{(34)}$.

$\mathrm{NF}-\mathrm{\kappa B}$ activity in the adipose tissue is involved in the regulation of energy metabolism, by promotion of energy expenditure and inhibition of adipose tissue growth ${ }^{(35)}$. Although increased NF- $\mathrm{\kappa B}$ activity has been noticed in the mouse and rat after a high-fat $\operatorname{diet}^{(36,37)}$, the effects of a high-fructose diet on NF- $\mathrm{B}$ protein expression in rat adipose tissue have not been assessed so far. In the present study, the fructose diet led to a significant decrease of NF- $\mathrm{B}$ p 65 subunit in the adipose tissue cytoplasmic fraction, whereas its translocation to the nucleus was apparently, but not significantly, increased. Additionally, an unaltered level of IкB in the

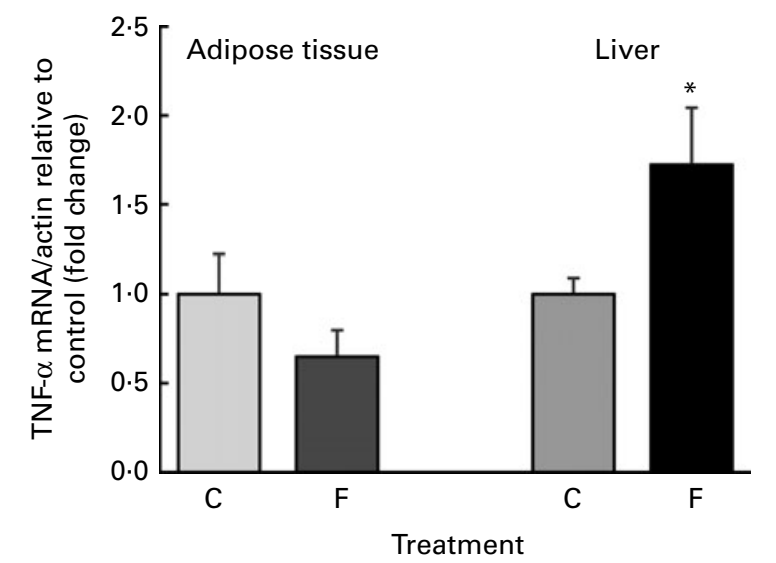

Fig. 3. TNF- $\alpha$ mRNA level in the adipose tissue and liver of control (C) and fructose-fed $(F)$ rats. Expression and relative quantification of mRNA level was done relative to the amount of $\beta$-actin. Values are means, with their standard errors represented by vertical bars, and are presented as fold of control $(n 9)$. * Mean value was significantly different from that of the $C$ rats $(P<0.05$; unpaired Student's $t$ test). 
(a)
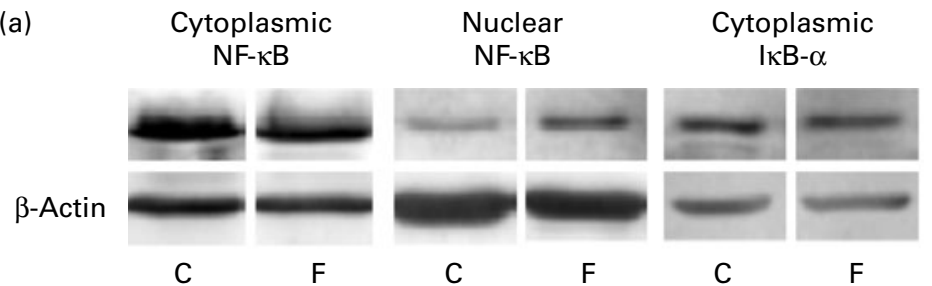

(b)

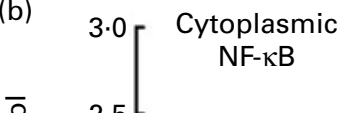

올

cytoplasmic fraction was observed, hence implicating a lack of IкB-dependent NF- $\kappa$ B activation. Previously, it was reported that MIF regulates inflammation through the mitogen-activated protein kinase/activator protein-1 signalling pathway, while MIF was not required for cytokine-induced NF- $\mathrm{B}$ activation $^{(38,39)}$. On the other hand, opposite actions of MIF and glucocorticoids on inflammation may be realised through the NF-кB signalling pathway, since MIF counteracts the action of glucocorticoids by interfering with its ability to increase IкB- $\alpha^{(40)}$. These facts, together with the present finding, led us to propose that NF- $\kappa \mathrm{B}$ activation in the adipose tissue of fructose-fed rats was attenuated due to the action of elevated CORT, implying dominant effects of glucocorticoids on inflammation. This proposal is further supported by our previous results that glucocorticoid receptor was activated in the adipose tissue of fructose-fed rats ${ }^{(30)}$, which is a well-known mechanism of negative regulation of NF- $\mathrm{KB}$ activation ${ }^{(41)}$.

One of the most important markers of metabolic inflammation in the adipose tissue is TNF- $\alpha$. It was proposed that MIF and TNF- $\alpha$ could function locally in a positive feedback to activate a proinflammatory response ${ }^{(15)}$. Moreover, endogenously released MIF could act in an autocrine fashion to overcome glucocorticoid inhibition of TNF- $\alpha$ production $^{(31)}$. In the present study, TNF- $\alpha$ mRNA level was not altered by the high-fructose diet within the adipose tissue in spite of increased MIF, which probably reflects the prevalence of the effects of glucocorticoids over those of $\mathrm{MIF}^{(31)}$.
However, a possibility that TNF- $\alpha$ is not the only cytokine involved in adipose tissue inflammation and that other cytokines, such as IL- 1 or IL- 6 , could mediate the proinflammatory effects of MIF cannot be excluded ${ }^{(42)}$.

Apart from its role as an inflammatory mediator and glucocorticoid counter-regulator, MIF also acts as an obesitydependent mediator of macrophage infiltration into the adipose tissue $\mathrm{e}^{(43)}$ and there are reports on the correlation between plasma MIF level and BMI in obese patients ${ }^{(44)}$ or between plasma MIF and weight gain in rats on a high-fat diet $^{(45)}$. In the present study, the fructose-rich diet exerted no significant effect on plasma MIF level and visceral adipose tissue mass, but the existence of a highly significant positive correlation between these parameters was confirmed.

Taking into account our present and previous findings, we propose that MIF production acts in concert with glucocorticoids to regulate the inflammatory response in the adipose tissue after high fructose consumption. Their coordinate action could represent a mechanism that limits the adverse consequences of a high-fructose diet on adipose tissue inflammation.

The liver is an essential organ for the maintenance of lipid, glucose and hormonal homeostasis. Fructose is a highly lipogenic sugar that has profound metabolic effects in the liver, inducing de novo lipogenesis, gluconeogenesis and chronic inflammation $^{(2)}$. In contrast to the adipose tissue, both MIF protein and mRNA levels in the liver were unchanged by 
(a)

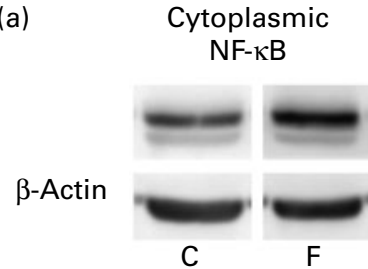

(b)

Cytoplasmic

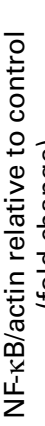
NF- $\kappa B$

the fructose-rich diet. This tissue-specific pattern of MIF expression after a high-fructose diet may be related to its role in the regulation of glucose metabolism in the adipose tissue, especially during an inflammatory response ${ }^{(46)}$. The metabolic function of MIF is unique to the adipose tissue, which was confirmed in MIF knockout animals or animals treated with neutralising anti-MIF antibody. These animals demonstrated a selective increase in insulin-mediated glucose uptake into the white adipose tissue after TNF- $\alpha$ treatment, while hepatic glucose production remained unaffected ${ }^{(33)}$. The role of MIF is also important for the regulation of macrophage infiltration into the adipose tissue and for modulation of visceral adipose tissue inflammation in the mouse model of insulin resistance ${ }^{(34)}$. Furthermore, the fructose-rich diet did not influence the level of CORT in the liver, but increased it in the adipose tissue. The differences in the glucocorticoid levels between the studied tissues could presumably result from altered prereceptor glucocorticoid metabolism: $11 \beta$ HSD1 protein and mRNA levels were increased in the adipose tissue of fructose-fed rats ${ }^{(25,30)}$, while the protein level was decreased in the liver ${ }^{(25)}$.

An additional difference between the effects of the highfructose diet in the adipose tissue and the liver was observed at the level of expression and cellular redistribution of NF- $\mathrm{KB}$. In the liver, the transcriptionally active p65 subunit was significantly increased in both cytoplasmic and nuclear fractions, which points to its sustained activation after high fructose consumption $^{(28)}$. Moreover, the level of IкB was significantly decreased in the cytoplasmic fraction, further confirming $N F-\kappa B$ activation. The activation of the NF- $\kappa B$ signalling pathway was consistent with the observed increase of TNF- $\alpha$ mRNA in the liver, demonstrating a hepatic inflammatory response elicited by the high-fructose $\operatorname{diet}^{(47,48)}$. Hepatic inflammation was most probably the result of increased influx of NEFA from the circulation ${ }^{(6,30)}$, which are derived from the adipose tissue ${ }^{(5)}$. Generation of TNF- $\alpha$ in the liver could lead to a vicious cycle of worsening insulin resistance via activation of inflammatory and stress signalling cascades, including NF- $\mathrm{kB}$ and c-Jun N-terminal kinase ${ }^{(49)}$. Interestingly, significantly increased MIF expression in the liver of patients with non-alcoholic fatty liver disease arises secondary to inflammation $^{(50)}$, so it should be considered as a consequence rather than as a causal factor of inflammation. Based on the present results, we may conclude that the hepatic inflammatory response to the high-fructose diet was mainly conducted through activated $\mathrm{NF}-\mathrm{\kappa B}$ signalling rather than through the action of $\mathrm{MIF}^{(47,48)}$. However, there is also a possibility of later onset of increased MIF expression in the liver, which could coincide with the development of hepatic insulin resistance and hepatosteatosis.

In summary, we propose that a high-fructose diet has tissue-specific effects on regulation of inflammation, as the fructose-promoted MIF-glucocorticoid dyad is essential for adipose tissue inflammation, rather than for hepatic inflammation. Further definition of MIF and glucocorticoid co-regulation of inflammation in the adipose tissue and liver may provide new strategies for manipulating the course of inflammatory and immune responses in overnutrition-induced metabolic disorders. 


\section{Acknowledgements}

The present study was supported by the project grant no. 41009 from the Ministry of Education, Science and Technological Development, Republic of Serbia. The authors gratefully appreciate Ivana Stojanovic for providing MIF antibodies and Djordje Miljkovic for providing primers for TNF- $\alpha$ and for critical reading of the manuscript. N. V. designed the study, analysed the data and wrote the paper. A. D. analysed the data and wrote the paper. D. V. M., A. V. and B. B. conducted the experiments and statistical analysis. G. M. designed the study and revised the paper before submission. All authors have approved the final manuscript. The authors declare that there are no conflicts of interest.

\section{References}

1. Rutledge AC \& Adeli K (2007) Fructose and the metabolic syndrome: pathophysiology and molecular mechanisms. Nutr Rev 65, S13-S23.

2. Dekker MJ, Su Q, Baker C, et al. (2010) Fructose: a highly lipogenic nutrient implicated in insulin resistance, hepatic steatosis, and the metabolic syndrome. Am J Physiol Endocrinol Metab 299, E685-E694.

3. Savage DB, Petersen KF \& Shulman GI (2007) Disordered lipid metabolism and the pathogenesis of insulin resistance. Physiol Rev 87, 507-520.

4. Weisberg SP, McCann D, Desai M, et al. (2003) Obesity is associated with macrophage accumulation in adipose tissue. J Clin Invest 112, 1796-1808.

5. Boden G, She P, Mozzoli M, et al. (2005) Free fatty acids produce insulin resistance and activate the proinflammatory nuclear factor-kappaB pathway in rat liver. Diabetes $\mathbf{5 4}$, 3458-3465.

6. Solinas G \& Karin M (2010) JNK1 and IKKbeta: molecular links between obesity and metabolic dysfunction. FASEB J 24, 2596-2611.

7. Cai D, Yuan M, Frantz DF, et al. (2005) Local and systemic insulin resistance resulting from hepatic activation of IKK-beta and NF-kappaB. Nat Med 11, 183-190.

8. Ghosh S, May MJ \& Kopp EB (1998) NF-к B and Rel proteins: evolutionarily conserved mediators of immune responses. Annu Rev Immunol 16, 225-260.

9. Wellen KE \& Hotamisligil GS (2005) Inflammation, stress, and diabetes. J Clin Invest 115, 1111-1119.

10. Tsigos C, Kyrou I, Chala E, et al. (1999) Circulating tumor necrosis factor alpha concentrations are higher in abdominal versus peripheral obesity. Metabolism 48, 1332-1335.

11. Uysal KT, Wiesbrock SM, Marino MW, et al. (1997) Protection from obesity-induced insulin resistance in mice lacking TNF-alpha function. Nature 389, 610-614.

12. Kleemann R \& Bucala R (2010) Macrophage migration inhibitory factor: critical role in obesity, insulin resistance, and associated comorbidities. Mediators Inflamm 2010, 610479 .

13. Bucala R (1996) MIF rediscovered: cytokine, pituitary hormone, and glucocorticoid-induced regulator of the immune response. FASEB J 10, 1607-1613.

14. Lue H, Kleemann R, Calandra T, et al. (2002) Macrophage migration inhibitory factor (MIF): mechanisms of action and role in disease. Microbes Infect 4, 449-460.

15. Calandra T, Bernhagen J, Mitchell RA, et al. (1994) The macrophage is an important and previously unrecognized source of macrophage migration inhibitory factor. $J$ Exp Med 179, 1895-1902.

16. Fingerle-Rowson GR \& Bucala R (2001) Neuroendocrine properties of macrophage migration inhibitory factor (MIF). Immunol Cell Biol 79, 368-375.

17. Flaster H, Bernhagen J, Calandra T, et al. (2007) The macrophage migration inhibitory factor-glucocorticoid dyad: regulation of inflammation and immunity. Mol Endocrinol 21, 1267-1280.

18. Wang M (2005) The role of glucocorticoid action in the pathophysiology of the metabolic syndrome. Nutr Metab (Lond) 2, 3 .

19. Staab CA \& Maser E (2010) 11beta-Hydroxysteroid dehydrogenase type 1 is an important regulator at the interface of obesity and inflammation. J Steroid Biochem Mol Biol 119, $56-72$

20. Barnes PJ (2010) Mechanisms and resistance in glucocorticoid control of inflammation. J Steroid Biochem Mol Biol 120, 76-85.

21. Spector $\mathrm{T}$ (1978) Refinement of the coomassie blue method of protein quantitation. A simple and linear spectrophotometric assay for less than or equal to 0.5 to 50 microgram of protein. Anal Biochem 86, 142-146.

22. Djordjevic A, Milutinović DV, Tanic N, et al. (2012) Identification of suitable reference genes for gene expression studies in tissues from fructose-fed rats. Adv Sci Lett 5 , $560-565$.

23. Livak KJ \& Schmittgen TD (2001) Analysis of relative gene expression data using real-time quantitative PCR and the 2(-Delta Delta C(T)) method. Methods 25, 402-408.

24. Nagai Y, Yonemitsu S, Erion DM, et al. (2009) The role of peroxisome proliferator-activated receptor gamma coactivator-1 beta in the pathogenesis of fructose-induced insulin resistance. Cell Metab 9, 252-264.

25. London E \& Castonguay TW (2011) High fructose diets increase 11beta-hydroxysteroid dehydrogenase type 1 in liver and visceral adipose in rats within 24-h exposure. Obesity (Silver Spring) 19, 925-932.

26. Rayssiguier Y, Gueux E, Nowacki W, et al. (2006) High fructose consumption combined with low dietary magnesium intake may increase the incidence of the metabolic syndrome by inducing inflammation. Magnes Res 19, 237-243.

27. Wada T, Kenmochi H, Miyashita Y, et al. (2010) Spironolactone improves glucose and lipid metabolism by ameliorating hepatic steatosis and inflammation and suppressing enhanced gluconeogenesis induced by high-fat and highfructose diet. Endocrinology 151, 2040-2049.

28. Roglans N, Vila L, Farre M, et al. (2007) Impairment of hepatic Stat-3 activation and reduction of PPARalpha activity in fructose-fed rats. Hepatology 45, 778-788.

29. Ye J \& Keller JN (2010) Regulation of energy metabolism by inflammation: a feedback response in obesity and calorie restriction. Aging (Albany NY) 2, 361-368.

30. Bursać B, Djordjevic A, Vasiljević A, et al. (2012) Fructose consumption enhances glucocorticoid action in rat visceral adipose tissue. J Nutr Biochem (In the Press).

31. Calandra T, Bernhagen J, Metz CN, et al. (1995) MIF as a glucocorticoid-induced modulator of cytokine production. Nature 377, 68-71.

32. Fingerle-Rowson G, Koch P, Bikoff R, et al. (2003) Regulation of macrophage migration inhibitory factor expression by glucocorticoids in vivo. Am J Pathol 162, 47-56.

33. Atsumi T, Cho YR, Leng L, et al. (2007) The proinflammatory cytokine macrophage migration inhibitory factor regulates glucose metabolism during systemic inflammation. J Immunol 179, 5399-5406. 
34. Verschuren L, Kooistra T, Bernhagen J, et al. (2009) MIF deficiency reduces chronic inflammation in white adipose tissue and impairs the development of insulin resistance, glucose intolerance, and associated atherosclerotic disease. Circ Res 105, 99-107.

35. Tang T, Zhang J, Yin J, et al. (2010) Uncoupling of inflammation and insulin resistance by NF-kappaB in transgenic mice through elevated energy expenditure. $J$ Biol Chem 285, 4637-4644.

36. Carlsen H, Haugen F, Zadelaar S, et al. (2009) Diet-induced obesity increases NF-kappaB signaling in reporter mice. Genes Nutr 4, 215-222.

37. Chung MY, Park HJ, Manautou JE, et al. (2012) Green tea extract protects against nonalcoholic steatohepatitis in ob/ ob mice by decreasing oxidative and nitrative stress responses induced by proinflammatory enzymes. J Nutr Biochem 23, 361-367.

38. Toh ML, Aeberli D, Lacey D, et al. (2006) Regulation of IL-1 and TNF receptor expression and function by endogenous macrophage migration inhibitory factor. J Immunol 177, $4818-4825$

39. Stojanovic I, Cvjeticanin T, Lazaroski S, et al. (2009) Macrophage migration inhibitory factor stimulates interleukin-17 expression and production in lymph node cells. Immunology 126, 74-83.

40. Daun JM \& Cannon JG (2000) Macrophage migration inhibitory factor antagonizes hydrocortisone-induced increases in cytosolic IkappaBalpha. Am J Physiol Regul Integr Comp Physiol 279, R1043-R1049.

41. De Bosscher K, Schmitz ML, Vanden Berghe W, et al. (1997) Glucocorticoid-mediated repression of nuclear factorkappaB-dependent transcription involves direct interference with transactivation. Proc Natl Acad Sci U S A 94, $13504-13509$.
42. Kudrin A, Scott M, Martin S, et al. (2006) Human macrophage migration inhibitory factor: a proven immunomodulatory cytokine? J Biol Chem 281, 29641-29651.

43. Skurk T, Herder C, Kraft I, et al. (2005) Production and release of macrophage migration inhibitory factor from human adipocytes. Endocrinology 146, 1006-1011.

44. Dandona P, Aljada A, Ghanim H, et al. (2004) Increased plasma concentration of macrophage migration inhibitory factor (MIF) and MIF mRNA in mononuclear cells in the obese and the suppressive action of metformin. J Clin Endocrinol Metab 89, 5043-5047.

45. Saksida T, Stosic-Grujicic S, Timotijevic G, et al. (2012) Macrophage migration inhibitory factor deficiency protects pancreatic islets from palmitic acid-induced apoptosis. Immunol Cell Biol 90, 688-698.

46. Toso C, Emamaullee JA, Merani S, et al. (2008) The role of macrophage migration inhibitory factor on glucose metabolism and diabetes. Diabetologia 51, 1937-1946.

47. Spruss A, Kanuri G, Wagnerberger S, et al. (2009) Toll-like receptor 4 is involved in the development of fructoseinduced hepatic steatosis in mice. Hepatology 50, 1094-1104.

48. Haub S, Kanuri G, Volynets V, et al. (2010) Serotonin reuptake transporter (SERT) plays a critical role in the onset of fructose-induced hepatic steatosis in mice. $A m J$ Physiol Gastrointest Liver Physiol 298, G335-G344.

49. Hotamisligil GS (2006) Inflammation and metabolic disorders. Nature 444, 860-867.

50. Akyildiz M, Gunsar F, Nart D, et al. (2010) Macrophage migration inhibitory factor expression and MIF gene -173 G/C polymorphism in nonalcoholic fatty liver disease. Eur J Gastroenterol Hepatol 22, 192-198. 